\title{
Movement of Atlantic bluefin tuna (Thunnus thynnus) as determined by satellite tagging experiments initiated off New England
}

\author{
Michael J.W. Stokesbury, Steven L.H. Teo, Andrew Seitz, Ronald K. O'Dor, and \\ Barbara A. Block
}

\begin{abstract}
Pop-up satellite archival tags were attached to 35 Atlantic bluefin tuna (Thunnus thynnus) off the New England coast of the United States of America in 1998, 2000, and 2001. The tags provided information on the horizontal and vertical movements and environmental preferences of bluefin tuna. Fish showed movement patterns that can be categorized by age and season. Mature individuals were linked to the Gulf of Mexico breeding grounds based on light level longitude and sea surface temperature latitude estimates of geolocation and a radiosatellite endpoint position. A track based on geolocation indicated that a single individual moved from the tagging release location to the Gulf of Mexico and back to New England waters. Tag-generated water column profiles of depth versus temperature were consistent with fish movement along the shelf and into the Gulf of Mexico. Adolescent fish moved from the New England offshore feeding locations to winter aggregations in the coastal shelf and slope waters of North and South Carolina. Bluefin tuna showed a preference for ambient temperatures that ranged from 14 to $26{ }^{\circ} \mathrm{C}$ in autumn and from 18 to $24{ }^{\circ} \mathrm{C}$ in winter.

Résumé : Nous avons fixé une étiquette émettrice satellite à déploiement automatique et à archivage à 35 thons rouges (Thunnus thynnus) au large de la côte de la Nouvelle-Angleterre des États-Unis d'Amérique en 1998, 2000 et 2001. Les étiquettes fournissent des renseignements sur les déplacements horizontaux et verticaux et sur les préférences de milieux des thons rouges. Les patterns de déplacement des poissons peuvent se caractériser en fonction de l'âge et de la saison. Les individus à maturité sont associés aux aires de reproduction du golfe du Mexique d'après les estimations de la longitude (selon l'intensité lumineuse) et de la latitude (selon la température de surface de la mer) fournies par le géopositionnement et le positionnement extrême par radio-satellite. Un itinéraire basé sur le géopositionnement montre qu'un individu s'est déplacé du point de marquage au golfe du Mexique pour ensuite retourner dans les eaux de la Nouvelle-Angleterre. Les profils d'utilisation des profondeurs de la colonne d'eau en fonction de la température fournis par les étiquettes sont compatibles avec des déplacements le long du plateau continental et dans le golfe du Mexique. Les poissons adolescents se déplacent des aires d'alimentation au large de la Nouvelle-Angleterre vers des aires de rassemblement d'hiver dans les eaux du plateau continental et du talus au large des Caroline du Nord et du Sud. Les thons rouges préfèrent les températures ambiantes qui varient de 14 à $26{ }^{\circ} \mathrm{C}$ à l'automne et de 18 à $24{ }^{\circ} \mathrm{C}$ en hiver.
\end{abstract}

[Traduit par la Rédaction]

\section{Introduction}

Atlantic bluefin tuna (Thunnus thynnus) are large, highly migratory pelagic fish that are distributed in the western Atlantic Ocean from tropical waters off Brazil (Mather et al. 1995) to polar waters off Newfoundland (Caddy et al. 1976) and south of Greenland (Mather et al. 1995). Bluefin tuna conserve metabolic heat and can tolerate ambient tempera- tures that range from 2.8 to $31.0{ }^{\circ} \mathrm{C}$ (Carey and Lawson 1973; Block et al. 2001) while maintaining a relatively constant body temperature (Carey and Teal 1969; Block et al. 2001; Blank et al. 2004). These fish forage in productive cool waters during the summer and return to warm water masses to spawn (Block et al. 1993, 2001; Mather et al. 1995). This gives bluefin tuna the broadest thermal niche of all species of the family Scombridae (Block et al. 1998a).

Received 17 October 2003. Accepted 18 June 2004. Published on the NRC Research Press Web site at http://cjfas.nrc.ca on 23 December 2004.

J17796

M.J.W. Stokesbury. ${ }^{\mathbf{1}}$ Biology Department, Dalhousie University, 1344 Oxford Street, Halifax, NS B3H 4J1, Canada, and Tuna Research and Conservation Center, Stanford University, Hopkins Marine Station, Oceanview Boulevard, Pacific Grove, CA 93950, USA.

S.L.H. Teo and B.A. Block. Tuna Research and Conservation Center, Stanford University, Hopkins Marine Station, Oceanview Boulevard, Pacific Grove, CA 93950, USA.

A. Seitz. Monterey Bay Aquarium, 886 Cannery Row, Monterey, CA 93940, USA.

R.K. O'Dor. Biology Department, Dalhousie University, 1344 Oxford Street, Halifax, NS B3H 4J1, Canada.

${ }^{1}$ Corresponding author (e-mail: mstokesb@dal.ca). 
Atlantic bluefin tuna are currently managed as two stocks in the Atlantic Ocean and Mediterranean Sea (National Research Council 1994). It is hypothesized that the western Atlantic Ocean stock spawns in the Gulf of Mexico (Richards 1976) and the Straits of Florida (Rivas 1954) and the eastern Atlantic Ocean stock in the Mediterranean Sea (Richards 1976). Larval tows support the hypothesis that these three areas are primary spawning grounds (Richards 1976; McGowan and Richards 1989).

Abundance estimates indicate that the western Atlantic Ocean stock of mature Atlantic bluefin tuna has decreased markedly since the 1970s (Magnuson et al. 2001), in spite of the recovery plan that was put in place by the International Commission for the Conservation of Atlantic Tunas (ICCAT) in the early 1980s. The current management plan assumes that mixing between the two stocks occurs at a low rate $\left(<4 \% \cdot\right.$ year $^{-1}$; National Research Council 1994). However, recent archival and conventional tagging data indicate that fish in the western Atlantic Ocean cross to the eastern Atlantic Ocean at a rate that ranges from $10 \%$ to $30 \%$ (Block et al. 2001). Increased understanding of the movement patterns and the level of mixing between the two stocks is crucial to improving the management and conservation of bluefin tuna (National Research Council 1994; Sissenwine et al. 1998; Magnuson et al. 2001).

Historically, conventional tag returns from Atlantic bluefin tuna tagged in the northwestern Atlantic Ocean have linked these fish to several regions. Tagging of bluefin tuna with conventional tags in St. Margaret's Bay, Nova Scotia, produced returns from the waters off New England, southwestern Nova Scotia, and the Gulf of St. Lawrence (Burnett et al. 1977). Also, two fish conventionally tagged off Massachusetts were recaptured in the Gulf of Mexico (Mather et al. 1995). Mather et al. (1995) proposed that after spawning, bluefin tuna migrated from the Gulf of Mexico through waters east of the Bahamas and off the southeastern United States. They then followed the eastern edge of the Florida Current to Cape Hatteras. Next, they followed the Gulf Stream northeastward, leaving at varying intervals to make their way north to various feeding grounds (Mather et al. 1995). It was also proposed that some bluefin tuna might follow the Gulf Stream into the northeast Atlantic Ocean to feeding grounds off Norway. The route of the southern return migration of adult bluefin tuna was less clear from the tagging results (National Research Council 1994).

Recently, investigators have used electronic tagging technology to examine the movements of Atlantic bluefin tuna (Block et al. 1998a, 2001; Lutcavage et al. 1999). Block et al. (1998a, 2001, 2002) reported results from a study using both archival data storage tags and pop-up satellite archival tags (PSATs) that investigated the migration and environmental preferences of electronically tagged fish released off the coasts of North Carolina and New England and in the Gulf of Mexico. Block et al. (2001, 2002) determined that bluefin tuna tagged in the western Atlantic Ocean exhibited four migratory behaviors over 1-3 years after tagging: western Atlantic residency without visiting a recognized spawning ground, western Atlantic residency with visitation to a known western spawning ground, western residency for 13 years with visitation to the known eastern spawning ground, the Mediterranean Sea, and transatlantic movement west to east and back. Western residency was the prevalent pattern for adolescent bluefin tuna, as they occupied offshore waters off North Carolina in the winter, the Gulf Stream in spring, and New England waters in summer and autumn.

Atlantic bluefin tuna electronically tagged in the North Carolina winter fishery resided in waters offshore of North and South Carolina and then arrived in summer and autumn in waters off New England. For fish tagged off North Carolina, the most likely place to recover an archival-tagged fish was New England, strongly linking the two groups of fish and the associated fisheries (Block et al. 2001). Also, although many bluefin tuna in New England waters are from a larger more mature component of the population, there remains a large overlap in the adolescent and early-breeding cohorts.

While the waters off New England were clearly important for many Atlantic bluefin tuna tagged in previous studies, some archival and pop-up satellite tagged fish released off North Carolina did not visit this area. Data from Block et al. (2001, 2002) provided strong evidence for a movement of fish from North Carolina waters to the Mediterranean Sea spawning grounds and to the area east of the Flemish Cap and south of Greenland. Fish moving from North Carolina to either the Mediterranean Sea or the Flemish Cap showed no association with waters off New England either on the way to the Flemish Cap or on their way to western or eastern known spawning grounds after residency in feeding areas (Block et al. 2001, 2002).

In a second study, using externally placed pop-up satellite tags, Lutcavage et al. (1999) reported on the movements of Atlantic bluefin tuna tagged in the Great South Channel off Massachusetts. Of 20 satellite tags deployed on fish in the Great South Channel, five reported from the mid-Atlantic east of $45^{\circ} \mathrm{W}$, the ICCAT stock management boundary line. Although most of the pop-up satellite tags surfaced on the western side of the stock boundary line, the major conclusion of the paper was that fish from New England travel toward the mid-Atlantic during the winter. The authors raised the possibility, based on these results, that bluefin tuna tagged off New England spawn in the mid-Atlantic.

In the current study, we examine the movements of Atlantic bluefin tuna tagged and released off New England with two types of pop-up satellite tags of increasingly sophisticated software generations. The evolution of the tag software and hardware permitted increased data acquisition during the 3 -year period of this study. The results of this study have important implications for bluefin tuna management and conservation and clarify previous data reported from this assemblage in the western Atlantic Ocean.

\section{Materials and methods}

Pop-up satellite tags were deployed on Atlantic bluefin tuna in three different years $(1998,2000$, and 2001) off the coast of Massachusetts. Tags were secured to the fish using two procedures of capture and release.

In autumn 1998, Atlantic bluefin tuna were captured using a purse seine by the fishing vessel Sea Rover. For release, the net was opened enough to permit the release of one bluefin tuna at a time. As the fish swam out of the net, one individual tagged it using a harpoon deployment procedure. A 
Table 1. Satellite tag hardware, software, and programing information.

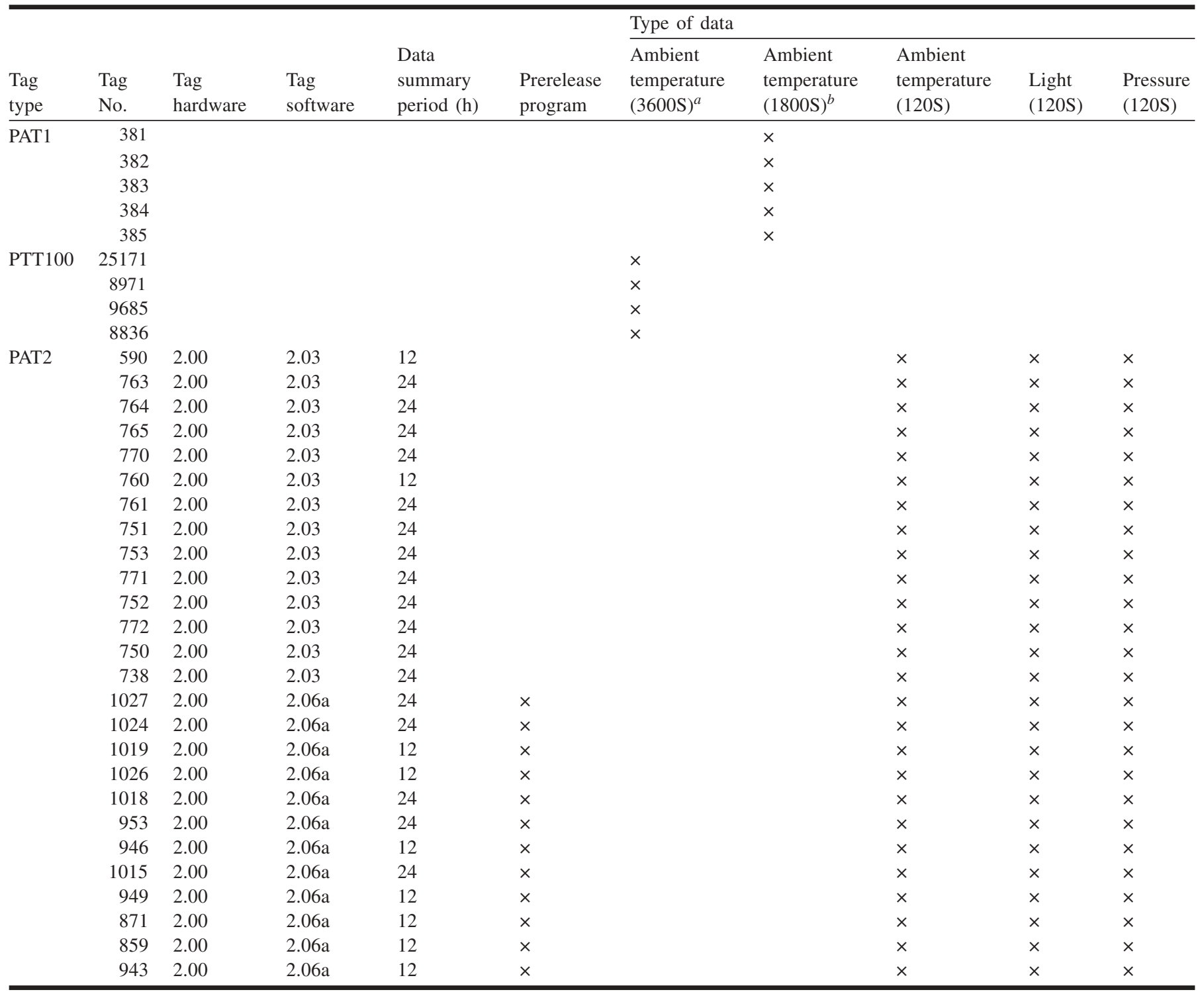

${ }^{a}$ The first 60 ambient temperature measurements are daily averages derived from hourly measurements from the previous 24-h period. The 61st ambient temperature measurement is the average for the 24-h period prior to the tags' programed report date.

${ }^{b}$ Ambient water temperatures are recorded every $0.5 \mathrm{~h}$ and archived for the first 60 days of deployment.

titanium dart anchor with the attached pop-up satellite tag was inserted close to the second dorsal fin. A pop-up satellite tag was secured to the titanium dart by a monofilament leader $(136 \mathrm{~kg})$ covered in shrink wrap to increase its stiffness (Block et al. 1998b). Two experienced purse-seine vessel captains estimated the sizes of the fish. Of the nine tags deployed, five were first-generation single-point PAT1 tags built by Wildlife Computers and four were single-point Microwave Telemetry PTT100 tags (Table 1). Both types of tags provided an endpoint location based on the Doppler shift of the tags' radio transmission to the Argos satellites (root mean square errors for class 2 and class 3 readings were 350 and $150 \mathrm{~m}$, respectively; Taillade 1992).

In 2000 and 2001, Atlantic bluefin tuna were captured by rod and reel using 120-kg line test and 9/0 to 11/0 Gamakatsu baited circle hooks. Fish were boated using a "lip hook", a short-handled gaff inserted into the lower jaw of the fish to pull it aboard the vessel. The fish were pulled through an opening in the transom of the vessel onto a wet vinyl mat on the deck of the boat using methods previously described by Block et al. (1998a, 1998b). The curved fork length (CFL) of the fish was measured (centimetres) prior to tagging. Only fish larger than $172 \mathrm{~cm}$ CFL were tagged. A titanium dart was inserted into the dorsal musculature at the base of the second dorsal fin so that the tag head was pushed though the pterygiophores, thus providing a solid point of attachment for the tag. The rubber shrink wrap covering the leader of the PSAT had an identification number and telephone contact that provided the opportunity for additional recapture information. A conventional dart tag was also attached on the opposite side of the second dorsal fin from the PSAT. The fish were then released by sliding them off the 
wet vinyl mat headfirst through the tuna door and into the water. This method was applied to fish as large as $287 \mathrm{~cm}$ CFL.

The three types of pop-up satellite tags acquired and transmitted data differently. PTT100 tags acquired ambient temperature data at 1-h intervals for the first 60 days of deployment and the day prior to the tag report. The tag then transmitted the daily mean temperature (calculated from the hourly readings) for the first 60 days and the day prior to the tag report. Wildlife Computer PAT1 tags acquired ambient temperature at 0.5 -h intervals for the first 60 days of deployment and transmitted the entire data archive. PAT2 tags acquired data in 60-s intervals for light, ambient temperature, and pressure and archived data in 120-s intervals to memory. Data were summarized into 12 - or 24 -h bins prior to transmission (Table 1). The summary data for each time period comprised percent distributions of time-at-depth and time-attemperature and temperature versus depth profiles that were generated by dividing the maximum dive during the interval into eight equally distributed points, inclusive of the surface and maximum depth. A minimum and maximum temperature at each of these depths was stored and transmitted.

In 2000 and 2001, PSATs (PAT2) with two versions of software (2.03 and 2.06a, respectively) were used. The PAT2 tags (software version 2.06a) were equipped with a prerelease program and an auto depth correction in the 2001 deployments. Therefore, if the tag prematurely detached from the fish and floated to the surface, it reported to the satellite 4 days after detachment. PAT2 tags (software version 2.03) deployed in 2000 did not have this program and drifted from the date of detachment from the fish until the preprogramed reporting date. However, the pressure sensor provided direct evidence of the date of tag prerelease from the fish. All PAT2 tags deployed in 2000 and 2001 provided a full archival record at 120-s intervals if recaptured (Table 1).

\section{Tag prerelease software}

Early-generation PAT tags had a tendency to release before the scheduled pop-up date (Gunn and Block 2001). Prerelease could be due to a variety of factors, including failure of the titanium dart to remain attached to the monofilament, failure of the stainless steel pin that is the point of attachment of the tag to the leader, and wearing through of the monofilament.

The first step in data analysis was to assess whether individual tags remained attached to the respective Atlantic bluefin tuna for the full duration of the deployment. This was not possible in the case of the Microwave Telemetry PTT100 tags. For Wildlife Computers PAT1 tags, the complete archive of external temperature data at 0.5 -h intervals allowed collection of an increased amount of data on external temperature to discern changes in water temperature in association with vertical and horizontal movements. Therefore, it was possible to estimate when the tag prematurely released for those tags that were on the fish for the period of time that the temperature data were archived (60 days after release). The tags for which it was possible to verify whether they remained on the fish and that produced endpoint positions were divided into two groups: (i) tags that remained attached, as determined by the temperature and pressure records or temperature alone and (ii) tags that were "drifters" for a period greater than 4 days prior to data transmission (the length of time preprogramed into the tag to activate transmission if the tag came prematurely to the surface).

\section{Geolocation}

Information on daily movements of Atlantic bluefin tuna was obtained from light-based calculation of longitude using PAT Decoder 7.08.0005 of Wildlife Computers (Hill 1994; Hill and Braun 2001) combined with latitude estimates based on sea surface temperature (SST) (Teo et al. 2004). The accuracy of these geolocation estimates was determined by comparing endpoint positions from pop-up satellite tags and global positioning system (GPS) with geolocation estimates based on light level longitude and SST latitude (Teo et al. 2004). Endpoint data based on radio transmissions at the surface from PAT2s on 49 fish (including 12 from this study) had a root mean square error for geolocation estimates of $1.30^{\circ}$ for light-based longitude and $1.89^{\circ}$ for SST-based latitude (Teo et al. 2004). Therefore, this geolocation validation provides an ellipse of error estimate around each point.

\section{Results}

A total of 35 Atlantic bluefin tuna were tagged with popup satellite tags in three seasons of autumn tagging (1998, 2000, and 2001) (Table 2) off New England. The tagged fish ranged from 173 to $287 \mathrm{~cm}$ CFL. Radio endpoint locations indicating the last position of the fish prior to tag release were obtained from 14 tags that transmitted within 4 days of tag release. A single tag recapture position of a bluefin tuna recaptured with a pop-up satellite tag attached was provided by the fishers' GPS (Fig. 1). The radio endpoint locations and GPS position indicate the region in which the fish were present at tag detachment, recapture, or, in the case of the engagement of the premature release program, the position of the tag 4 days after detachment. These radio transmission endpoints indicate that most of the tagged fish moved due south from the initial tagging location off Massachusetts. Three tags $(381,382$, and 1026) reported endpoints close to the tagging site after short deployments of 10, 12, and 4 days, respectively. Tags 381 and 382 remained attached to the fish for the intended term of deployment. Tag 1026 was attached to a fish that died shortly after tagging and owing to the prerelease program reported 4 days after the death of the fish. One tag (1027) reported an endpoint close to the tagging site after 236 days at liberty. A single tag (859) also reported an endpoint from an area off-shelf south of Halifax, Nova Scotia, after 105 days at liberty. A single tag (383) reported an endpoint off New Jersey. Seven tags (590, 949, 946, 1018, 1019, 1024, and 943) reported endpoint positions from continental shelf and slope waters off the Carolinas (Fig. 1). One tag (1015) reported an endpoint position in the eastern slope waters of the Gulf of Mexico on 3 February 2002 (Fig. 1). Commercial fishers and beachcombers recovered two tags. Tag 770 was returned when a commercial longline vessel captured the fish off the coast of New Jersey, and the fisher provided a GPS position for the recapture point. Tag 763 was found detached from the fish on a beach in the Bahamas. A single tag leader (871) was recovered after tag release by an American purse seiner, providing an endpoint for the tagged fish (Fig. 1). 


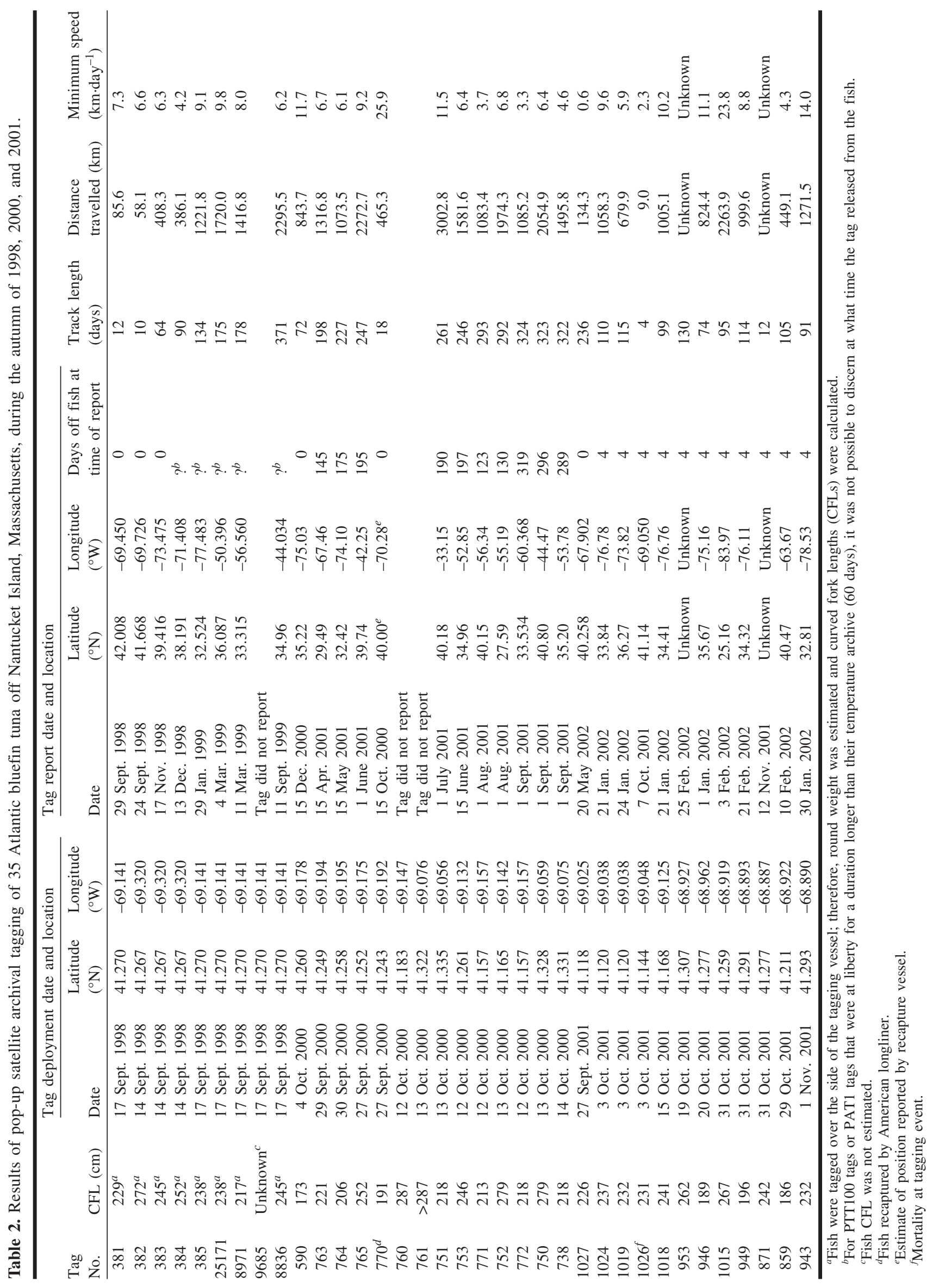


Fig. 1. Position data from pop-up satellite tags deployed on Atlantic bluefin tuna off Massachusetts (green triangle $=$ release location) in 1998, 2000, and 2001 obtained from radio transmission endpoints to the Argos satellite system (yellow squares, $N=14$ ), tag recapture (yellow square with $\times, N=1$ ), and leader recapture (red square with $\times, N=1$ ) positions and geolocation estimates based on light level longitude and sea surface temperature (SST) latitude estimates (white circles, $N=645$ ). The endpoint location for tag 1026 is obscured by the symbol representing the release location.

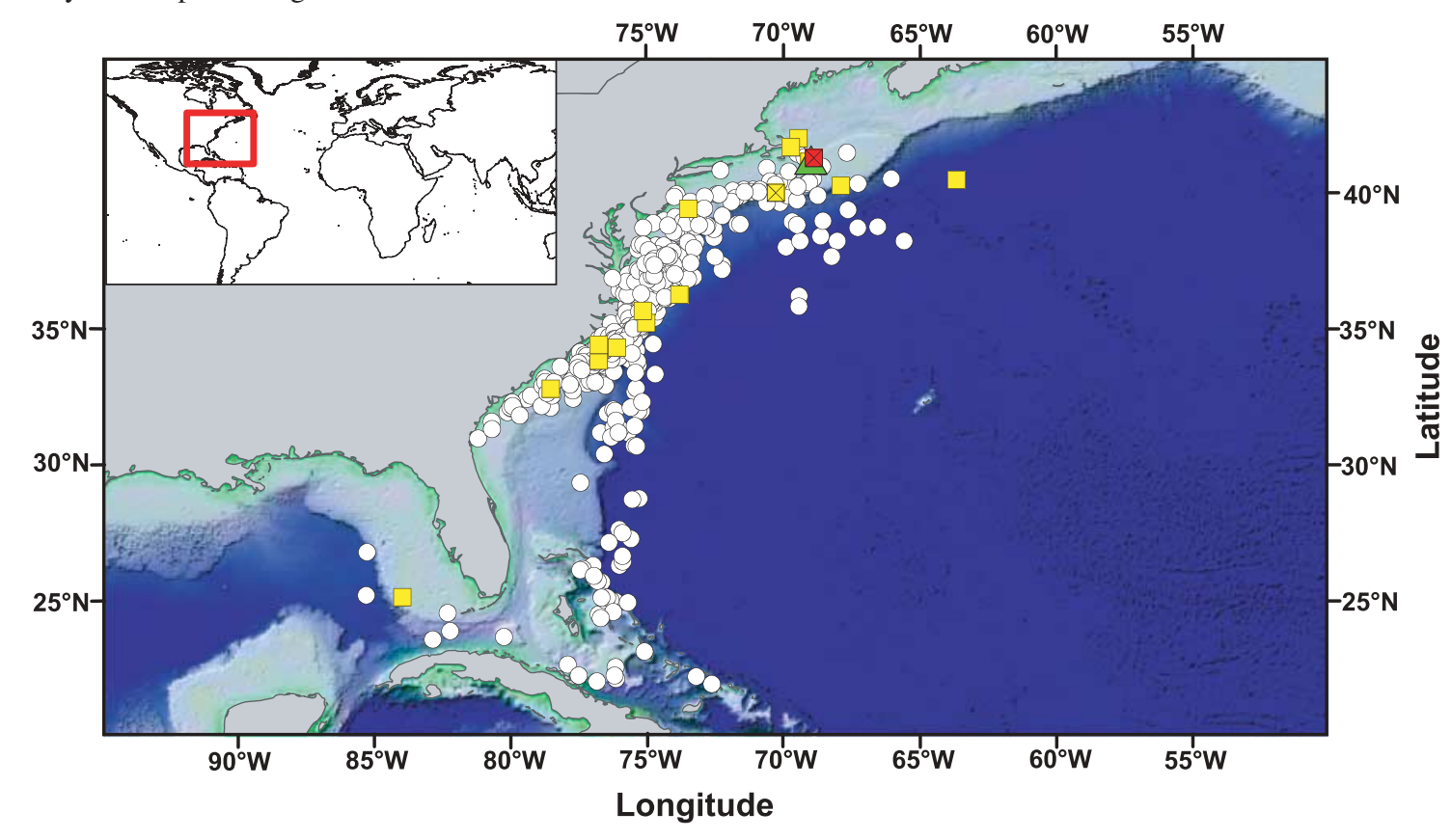

Two mature Atlantic bluefin tuna (1015 and 1027) that were tagged off New England moved into the Gulf of Mexico spawning area. Bluefin tuna 1015 moved south from New England along the continental shelf of the Mid-Atlantic Bight and into North Carolina waters by late November. This bluefin tuna remained in on shelf waters off North Carolina in the winter months and slowly moved into slope waters and then south along the Blake Plateau. This fish traveled south across the Bahama Banks $\left(25^{\circ} 00^{\prime} \mathrm{N}\right.$, $75^{\circ} 36^{\prime} \mathrm{W}$ ) into off-shelf waters in December and into the Gulf of Mexico in mid-December. It remained in the Gulf of Mexico until the PSAT reported in early February from slope waters off Florida (Fig. 2a). The estimated geolocation track of 1015 is consistent with the water column structure and maximum depth data obtained from the temperaturedepth profiles from the PSAT (Fig. 2b). The data indicate that this fish was bathymetrically restricted in diving activity while in the shelf waters off New England and North Carolina and then began a period of deeper dives in off-shelf waters. During the portion of the track that the fish was off New England and in the waters of the Mid-Atlantic Bight, the temperatures were cool $\left(16-20{ }^{\circ} \mathrm{C}\right)$. Ambient temperatures increased as the fish moved south along the US continental shelf, corroborating geolocation estimates of southward movement. After a period of residency in winter off North Carolina, the fish moved off the Carolina shelf. It moved into the Straits of Florida and then into the Gulf of Mexico in December. A warm surface water mass and deep thermocline are characteristic of the Straits of Florida and Gulf of Mexico waters. The pop-up endpoint position places the fish in the eastern Gulf of Mexico.

Atlantic bluefin tuna 1027 had a pop-up endpoint position located $171.15 \mathrm{~km}$ from the initial deployment location off
New England after 8 months at liberty. This indicates that this fish showed fidelity, returning to the region where it was tagged. This is consistent with conventional tagging records from this area. Geolocation estimates indicate that a complex migration occurred between tag deployment and pop-up. Bluefin tuna 1027 displayed a pattern of movement from New England south along the continental shelf in the period from October to March (Fig. 2c). A geolocation estimate indicates that the fish moved to the west into a region consistent with the Gulf of Mexico in March. Because of the bluefin tuna's deep diving behavior, and a lack of transmissions, the reported data did not provide many daily light level positions for estimating geolocation. This is consistent with implantable archival tag data from bluefin tuna that entered the Gulf of Mexico and pop-up satellite tag data from the Gulf of Mexico. These data indicated extensive deep diving during the period that the fish enter the Gulf of Mexico (Block et al. 2001, 2002). For 18 days before and 17 days after the single geolocation (9 March 2002) in the Gulf of Mexico, no light level data were reported. The temperature-depth profiles from this tag, which were also limited in number, indicate a period of on-shelf bathymetrically limited diving at the beginning of the track and movement from a cooler water mass through the Gulf Stream and into a warmer water mass consistent with the Gulf of Mexico during March (Fig. 2d). This water mass had a $25-26{ }^{\circ} \mathrm{C}$ maximum surface water temperature and a 50-m themocline depth, which are consistent with those observed for this period on fish tagged in the western Gulf of Mexico (B.A. Block and S.L.H. Teo, unpublished data). After the fish was in the Gulf of Mexico, it had a period of deep diving and entered water masses cooler than the Gulf of Mexico. This corroborates geolocation estimates that indicate that the fish 


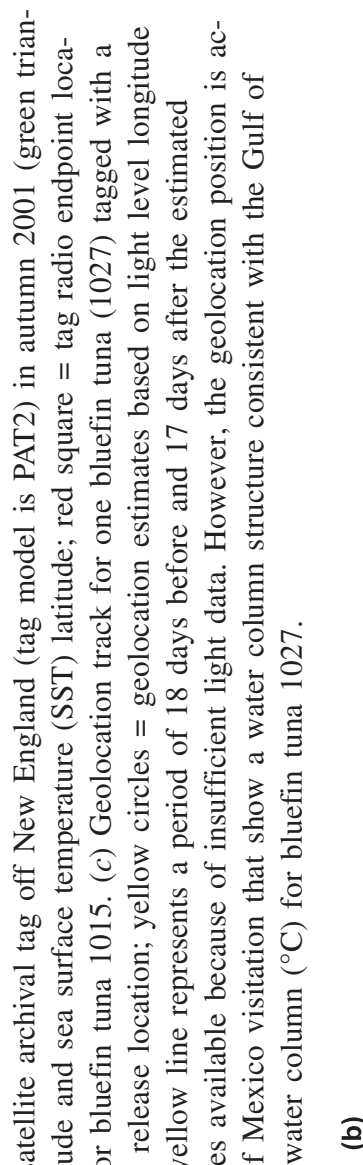

苛苛

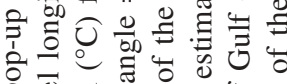
¿

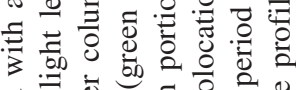

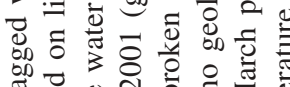

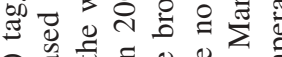

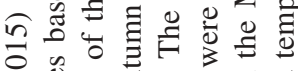

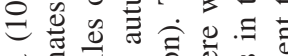

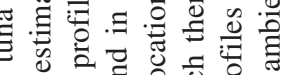

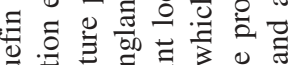

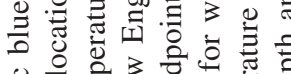

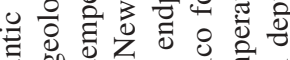

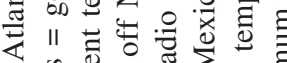

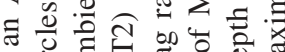
ᄒᄒ

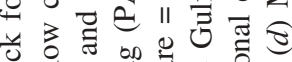

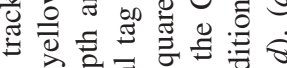

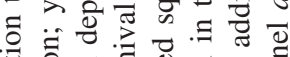

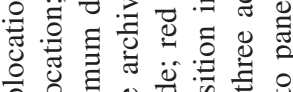

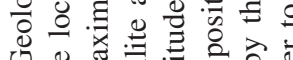
ช

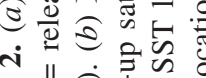

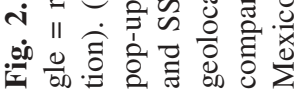
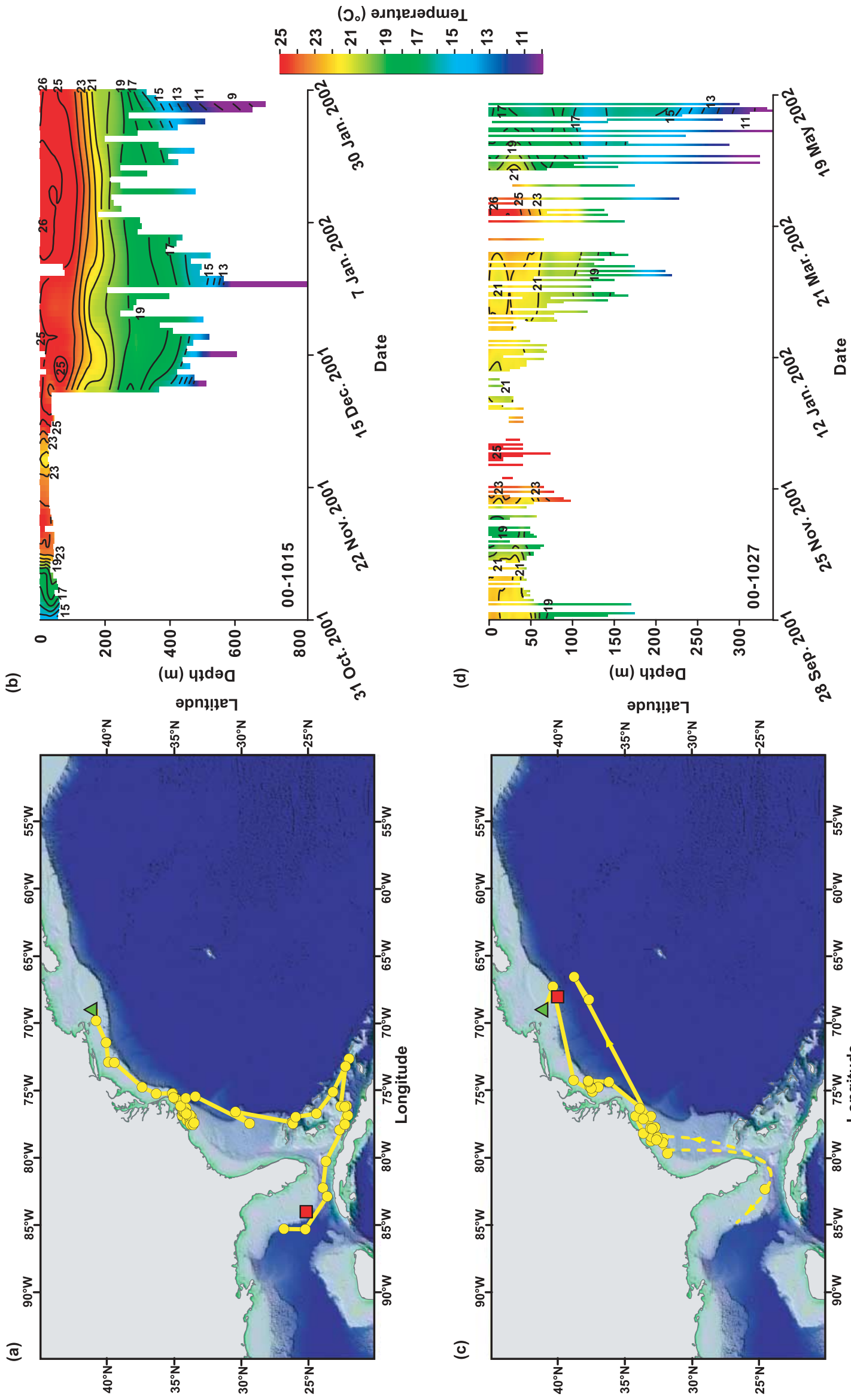
moved to the north. Geolocation estimates indicate that this fish was in the region of the Charleston Bump $\left(29^{\circ} 54^{\prime} \mathrm{N}\right.$, $76^{\circ} 18^{\prime} \mathrm{W}$ ) and then moved to waters off the GeorgiaCarolina shelf before returning to New England (Fig. 2a). One geolocation position (26 March 2002; $32^{\circ} 65^{\prime} \mathrm{N}$, $\left.78^{\circ} 66^{\prime} \mathrm{W}\right)$ as the fish moved north to the Carolina shelf was $19.49 \mathrm{~km}$ from a geolocation position (11 February 2002; $\left.32^{\circ} 74^{\prime} \mathrm{N}, 78^{\circ} 48^{\prime} \mathrm{W}\right)$ recorded during the fish's movement south, suggesting fidelity to this location. The fish moved from Carolina waters into the Gulf Stream and spring geolocation estimates place the fish on a cold $\left(9^{\circ} \mathrm{C}\right)$ frontal edge. The tag's endpoint position was $171.15 \mathrm{~km}$ from its point of release.

The seasonal movements from New England of potentially mature (>198 cm CFL) and adolescent (<198 cm CFL) Atlantic bluefin tuna are shown in Fig. 3. In the autumn (Fig. 3a) and winter (Fig. 3b) seasons, based on the autumnal equinox and winter solstice, both adolescent and mature bluefin tuna generally remain aggregated along the North American continental shelf and slope waters between New England and North Carolina. However, in the winter months, bluefin tuna, which are assumed by length measurements to be adolescent, aggregate in the Carolinas. Mature fish also pass through the Carolina shelf waters and move south to Blake's Plateau and to the waters of the Bahamas and the Gulf of Mexico in the winter months.

Atlantic bluefin tuna showed seasonal differences in their ambient temperature preferences (Fig. 4). Ambient water temperatures recorded by the PAT2 tags indicate that the bluefin tuna occupied similar water temperatures during autumn and winter with slightly broader temperatures experienced in autumn. In autumn, bluefin tuna spent $95 \%$ of the time in ambient water temperatures from 14 to $26{ }^{\circ} \mathrm{C}$ (Fig. 4). In winter, the bluefin tuna had narrower preferences in ambient temperatures spending $93.5 \%$ of the time in water from 18 to $24{ }^{\circ} \mathrm{C}$ (Fig. 4 ).

Archival data logged in the memory of two PAT2 tags were recovered from Atlantic bluefin tuna, one upon recapture (770) and one upon recovery of the tag off a beach (763). Bluefin tuna 770 provided 14 days of high-resolution data on diel diving patterns. This fish occupied deeper depths during the night $(31.54 \pm 35.82 \mathrm{~m}$, mean \pm SD) than during the day $(20.88 \pm 21.44 \mathrm{~m})$. Tag 763 was not analyzed because of a nonlinear depth drift.

Ten PAT2s, which were deployed prior to the development of the prerelease software program, detached from the Atlantic bluefin tuna prematurely (more than 4 days prior to the preprogramed release date) and drifted for from 123319 days after release (Table 2). These tags were not included in the location analysis above. These tags were attached to fish for 1-23 weeks prior to detachment. The endpoints of these drifting tags provide information on movement of tags that detach early from bluefin tuna. The tags all exhibited a general drift off the continental shelf to the east and northeast following the general path of the Gulf Stream. Several of the tags reported endpoint positions in the mid-Atlantic region (Fig. 5).

\section{Discussion}

The pop-up satellite tag positional data sets from three sources (radio endpoints, recovery location, and light level longitude and SST latitude estimations of geolocation) provided a total of 661 days of position data on the assemblage of Atlantic bluefin tuna found off New England. For the Argos radio position data, the quality of the endpoint location was calculated by the Argos system. The restriction of endpoint locations to accuracy class 2 or 3 ensured that the endpoint locations were likely to have an accuracy better than $350 \mathrm{~m}$. If the tag drifted for 1-4 days, it was possible that the tag had moved up to $1.5^{\circ}$ from the actual fish location based on drift rates calculated from transmitting tags. The estimated geolocation positions have a reported error estimate that is less than $2^{\circ}$ around the geolocation based on comparisons of satellite endpoints, GPS points, and estimated geolocations (Teo et al. 2004). The data sets demonstrate that bluefin tuna from this region, if tagged and tracked for less than a year, are most likely to be found in the western Atlantic Ocean on the North American continental shelf, the North American slope waters, or the Gulf of Mexico. These results are consistent with previously reported implantable archival tag data (Block et al. 2001) but differ in several significant respects to a prior pop-up satellite tag study on this same assemblage of fish (Lutcavage et al. 1999).

The satellite tags placed on Atlantic bluefin tuna in this study remained attached primarily for the autumn and winter seasons ( $<6$ months) and on a single fish into the spring season (approximately 8 months). The position data collectively show a pattern of migration by season where the bluefin tuna leave New England, move southward along the North American continental shelf, and reside in the vicinity of the North Carolina shelf. Data indicate that some fish move into the South Atlantic Bight and that two of the fish entered the Gulf of Mexico. Bluefin tuna 1015 represents the first record of a bluefin tuna being electronically tagged in New England and confirmed by radio endpoint position to visit the Gulf of Mexico breeding ground. Geolocation estimates for this fish indicate that it entered the Gulf of Mexico in December and was in the eastern slope waters of the Florida shelf when the tag popped off on 2 February 2002. Bluefin tuna 1027 entered the Gulf of Mexico in March. Bluefin tunas 1015 and 1027 recorded maximum depth and ambient temperature data consistent with their movements into the Gulf of Mexico. The data were similar to those of an implantable archival tagged bluefin tuna (98-512) previously reported (Block et al. 2001). This fish was tagged off Hatteras, North Carolina, and in 1 year moved to the north of the Gulf Stream in spring and then south along the continental shelf into the Gulf of Mexico and back to the waters of the Mid-Atlantic Bight. In this study, bluefin tuna 1027 moved to the Gulf of Mexico in March and then returned to waters off New England, indicating fidelity to the New England feeding aggregation after migration into the Gulf of Mexico. The tag detached from this fish on 20 May 2002, the preprogramed date of release, 236 days after tag and release. A portion of this 236-day track overlaps the track of a bluefin tuna that was pop-up satellite tagged in the Gulf of Mexico (B.A. Block, unpublished data) and moved into the North Atlantic. Consistent with these tracks is a propensity for deep diving that prevents obtaining light data and estimates of longitude. The release and recapture 334 days later of 
Fig. 3. Seasonal movements in $(a)$ autumn and $(b)$ winter and spring of Atlantic bluefin tuna tagged off New England. Autumn is defined as the period between the autumnal equinox and the winter solstice; winter is the period between the winter solstice and the spring equinox; and spring is the period between the spring equinox and the summer solstice. Maturity was assigned based on curved fork length (CFL) (white circles = adolescent bluefin tuna and are defined as $<198 \mathrm{~cm}$ CFL; yellow circles = potentially mature bluefin tuna and are define as $>198 \mathrm{~cm}$ CFL; green triangle $=$ release location; yellow square with $\times=$ tag recapture; red square with $\times=$ leader recapture; orange $=$ spring locations for one mature bluefin tuna 1027; squares $=$ Argos radio endpoint locations; circles $=$ geolocation estimates based on light level longitude and sea surface temperature (SST) latitude).
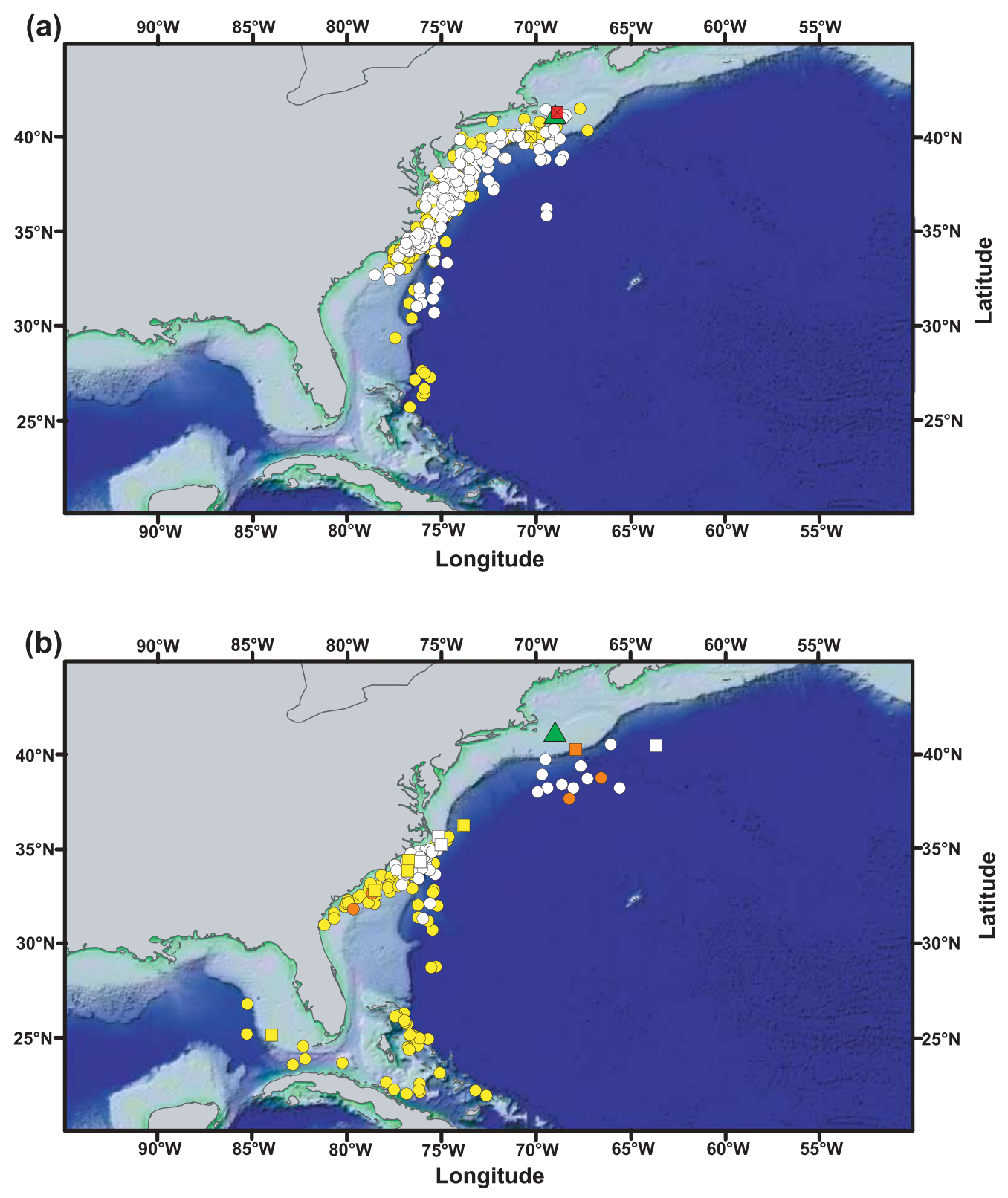

bluefin tuna 871 (leader recapture) indicates that this fish also showed fidelity to the New England feeding aggregation.

Geolocation estimates provide some distinctions between the movements of adolescent and mature Atlantic bluefin tuna. Movements of tagged adolescent bluefin tuna were recorded for durations of 18-114 days postrelease show a general distribution to the south of New England waters. In all but one case, these tuna migrated to the region along the North American continental shelf and remained in shelf waters north of North Carolina. Maximum depth records (28-
$40 \mathrm{~m}$ ) from these tags indicated that the dives of the bluefin tuna were depth limited, indicating that they remained in shelf waters. A single tagged adolescent bluefin tuna (tag $859,186 \mathrm{~cm}$ CFL) moved to off-shelf waters south of Halifax in February. This is similar to an off-shelf movement pattern for adolescent bluefin tuna observed by Mather et al. (1995) and Block et al. (2001).

In the first weeks of their autumnal southern migration, mature Atlantic bluefin tuna display movement patterns similar to those of adolescent bluefin tuna moving along the continental shelf and Mid-Atlantic Bight and into Carolina 
Fig. 4. Time at temperature distribution of Atlantic bluefin tuna tagged with pop-up satellite tags (PAT2) in 2000 and 2001. Twelve bluefin tuna were tagged and released and provided transmissions that were used to construct the graph. The tags reported ambient temperature data for a total of 293 days $(N=12$, mean $=24.42, \mathrm{SD}=16.91$ ) during the autumn (solid bars) (autumn equinox

(22 September) to winter solstice (21 December)) for 2000 and 2001. Four bluefin tuna were at large, retained their tags, and reported data for a total of 85 days $(N=4$, mean $=21.33, \mathrm{SD}=14.57)$ during winter (stippled bars) (winter solstice $(21 \mathrm{December})$ to spring equinox (20 March)) for 2001 and 2002.

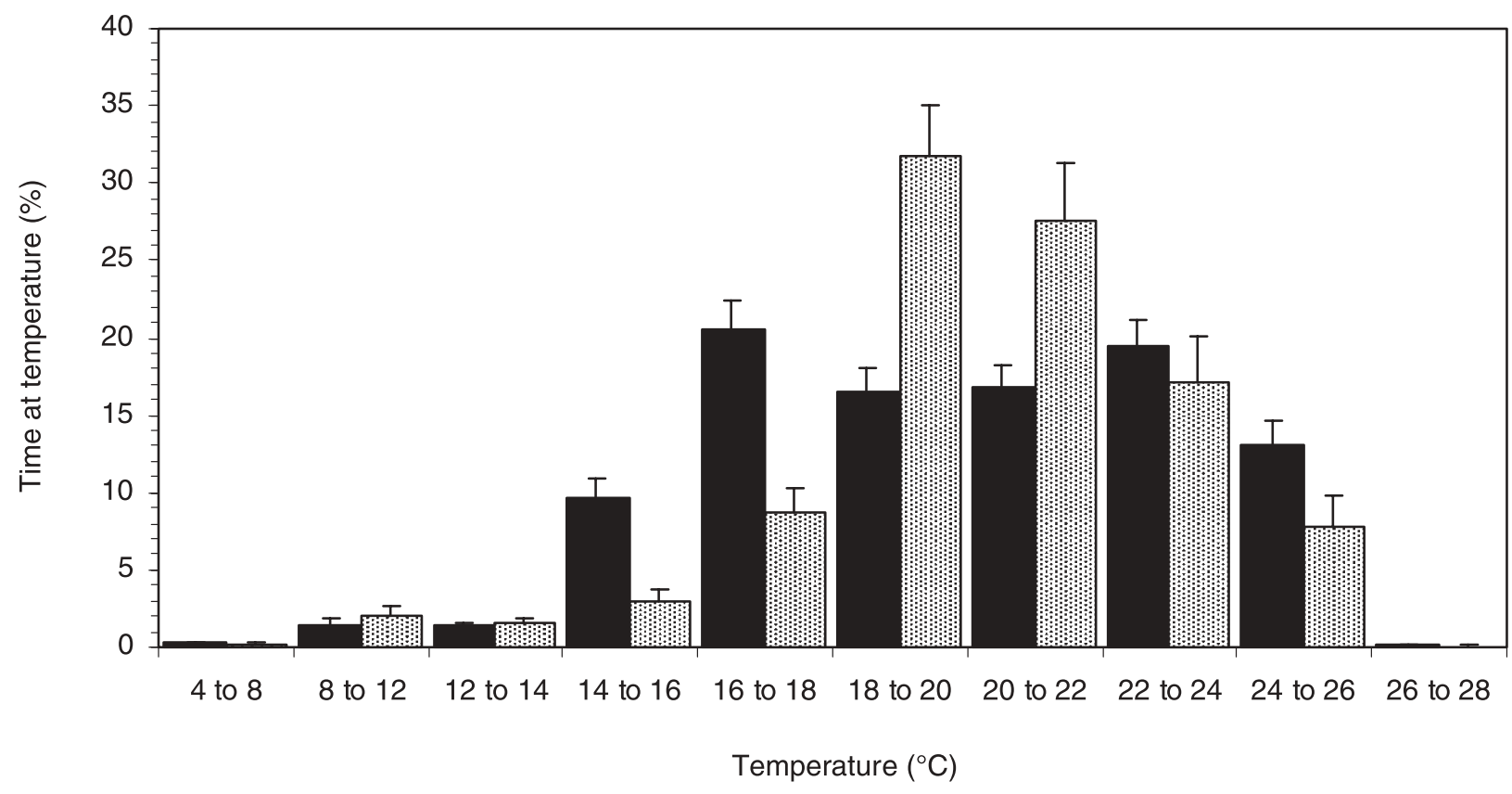

Fig. 5. Argos radio endpoint locations for 10 PAT2 tags that were confirmed by pressure data (2000 and 2001 releases) to have prematurely released from Atlantic bluefin tuna and drifted for from 123-319 days prior to reporting (triangle = release location; squares = Argos endpoints for drifting tags).

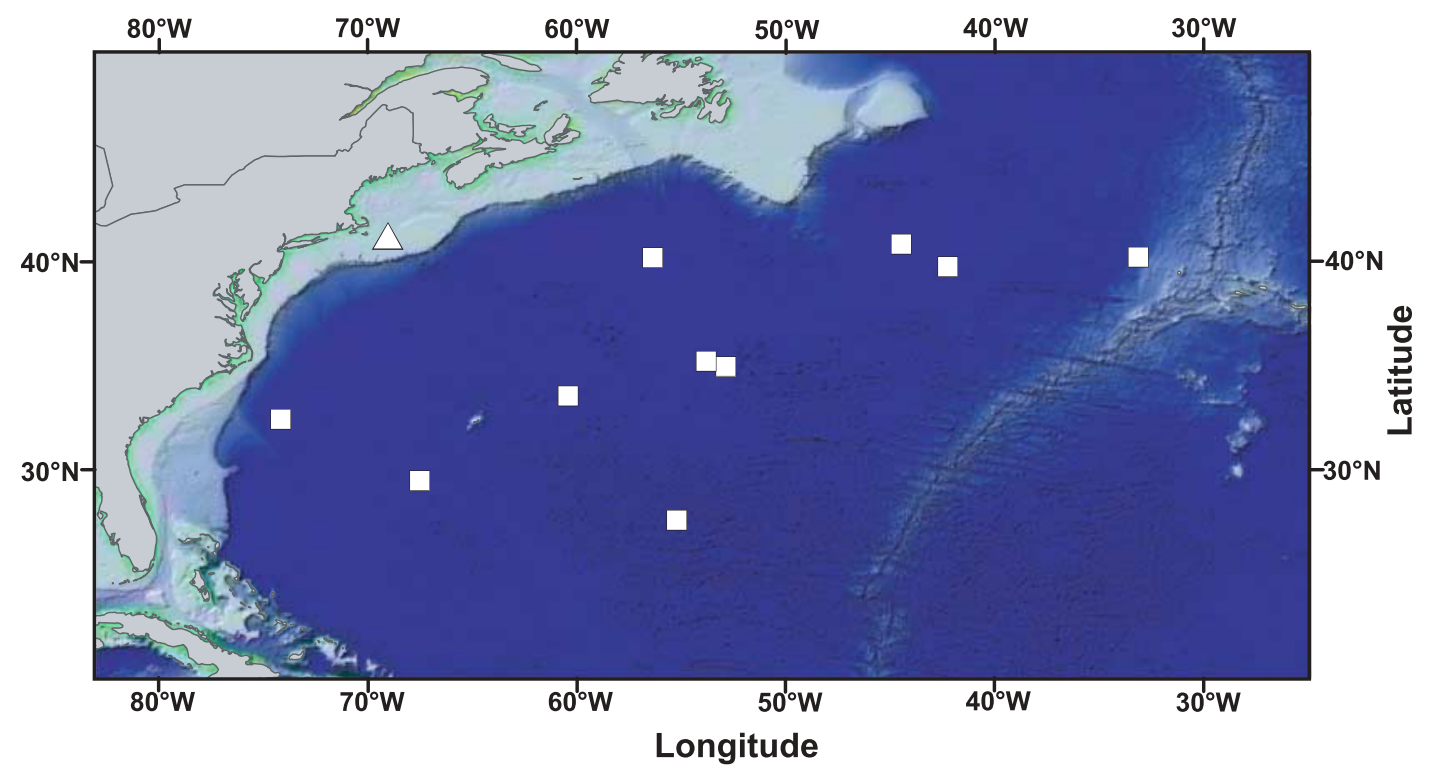

shelf waters. During winter months, however, mature bluefin tuna moved to positions farther south than adolescent bluefin tuna, including the Blake Plateau, Bahamas, and Gulf of Mexico. The passage of fish through the Carolinas region is consistent with previous studies showing that fish tagged in the Carolinas region moved to the south or occasionally into western breeding regions (Block et al. 2001, 2002).
The movements of Atlantic bluefin tuna were seasonal. All fish, whose tags remained on long enough to record a movement to the south, indicated migration along the shelf and toward the Carolinas after a period of autumn residency in the waters off New England. Bluefin tuna with implantable archival tags displayed similar movements south after SSTs cooled to $11-12^{\circ} \mathrm{C}$ (Block et al. 2001, supplemental data). 
Winter geolocation estimates and pop-up satellite tag endpoint positions indicate a winter distribution of bluefin tuna from waters off the Carolinas to the Blake Plateau and Gulf of Mexico.

Atlantic bluefin tuna showed a preference for waters with temperatures from 14 to $26^{\circ} \mathrm{C}$ during the autumn. During the winter, bluefin tuna appeared to reside in a narrower temperature range centered on $18-24{ }^{\circ} \mathrm{C}$. In winter off North Carolina, the water column is generally within this temperature range (Block et al. 2001; Boustany et al. 2001).

Pop-up satellite tags of earlier generations that detached prematurely from tagged Atlantic bluefin tuna and were not equipped with prerelease software drifted toward the midAtlantic prior to reporting. Four of the 12 free-drifting tags $(30 \%)$ reported from the eastern Atlantic Ocean ICCAT management zone (east of $45^{\circ} \mathrm{W}$ ). This is in contrast with the pop-up satellite tags that remained attached to the bluefin tuna that showed no movement into the eastern management zone and indicated a western residency period after release. Importantly, this study only covered the 8-month period after tagging and is consistent with Carolinas pop-up satellite tagging studies that suggested western residency for most fish in the first 8 months after release. However, implantable archival tags have shown that 1-3 years after release, bluefin tuna may move into the eastern Atlantic or Mediterranean. While short-term studies indicate western residency of bluefin tuna tagged in the autumn assemblage, it remains possible that bluefin tuna tagged for longer durations will move to the eastern Atlantic Ocean.

The results of this study differ from those of Lutcavage et al. (1999) who used an early generation of pop-up satellite tags that lacked pressure sensors and premature release software. The major contrast between the two studies is that in the current study, tags that remained attached to fish showed positions that were distributed primarily on the North American continental shelf and slope waters due south of New England and, importantly, recorded movements into known western breeding grounds in the Gulf of Mexico and the Florida Straits. Only drifting tags from the current study show agreement with the results of Lutcavage et al. (1999). Several studies have pointed out the challenges of interpreting the results of the earlier generations of pop-up satellite tags that lacked pressure sensors or temperature sensors that recorded significant archival data (Gunn and Block 2001). The lack of archival data makes the determination of when and where the tags released from the bluefin tuna highly challenging to discern (Gunn and Block 2001). Block et al. (2002) reported that results from studies that used singlepoint pop-up satellite tag technology to track bluefin tuna (i.e., Block et al. 1998a; Lutcavage et al. 1999) must be viewed with extreme caution if tags are interpreted beyond the period of the data archive. Clarifying what the New England assemblage of fish do and how much mixing occurs between this assemblage and fish from the eastern Atlantic Ocean is of critical importance. It is up to the electronic tagging community to carefully present the results from electronic tagging studies and qualify any uncertainty in positions.

This tagging study was initiated in the autumn and selected for Atlantic bluefin tuna moving from New England waters toward winter feeding and breeding grounds. These results indicate that fish tagged in the autumn feeding aggre- gation off New England feed in summer and early autumn in New England waters and in winter in Carolinas waters, consistent with the archival tagging results reported by Block et al. (2001). Also, our results are consistent with prior archival tagging results that tightly link the commercial and recreational fisheries off New England and the Carolinas (Block et al. 2001).

The results of this study represent only a short duration of activity for a long-lived pelagic species. Each Atlantic bluefin tuna is at a distinct period in its life cycle and their behavior might be different if studied for longer durations. Deployment of implantable archival tags that log multiple years of behavior is crucial for understanding the longer term biology and behavior of bluefin tuna (Block et al. 2001, 2002). Tagging data indicate that bluefin tuna movements are complex. Tag prerelease is an ongoing problem for external implantation of pop-up satellite tags. In addition, data compression and uplinking to the satellite are influenced by the state of the antenna, which is often damaged after long durations of attachment. Long-duration tracks spanning multiple years may best be obtained by tagging with implantable archival tags. However, efforts to reduce the size of pop-up satellite tags and improved attachment techniques may help to lengthen their duration of attachment. Efforts to continue electronically tagging bluefin tuna off New England with tags that remain in place for multiple years are necessary to discern the relationship of these fish with eastern assemblages over durations longer than 12 months.

\section{Acknowledgements}

This study was supported by grants from the Packard, Disney, and Monterey Bay Aquarium Foundations. M.J.W.S. was supported by a Natural Sciences and Engineering Research Council of Canada IPGS scholarship, a Dalhousie scholarship, and a Natural Sciences and Engineering Research Council of Canada grant to R.K.O. The National Marine Fisheries Service assisted in the recovery of the tags. We thank W. Whippen and R. Whorley for additional financial support and vessel access that made this study possible in New England. L. Ingrande and Captains C. Ingrande and S. Ingrande were instrumental in the tagging effort aboard the F/V Sea Rover in 1998. We thank W. Whippen for the donation of his vessel Tightline and his expertise in 2000, R. Whorley for providing his vessel Leslie Anne, and Captain G. Stuve for providing his skill as a Captain and for his enthusiasm for bluefin tuna and his expertise in 2001. We thank H. Dewar, A. Boustany, and J. Ganong for logistical support and A. Walli for figure preparation.

\section{References}

Blank, J.M., Morrissette, J.M., Landeira-Fernandez, A.M., Blackwell, S.B., Williams, T.D., and Block, B.A. 2004. In situ cardiac performance of Pacific bluefin tuna hearts in response to acute temperature change. J. Exp. Biol. 207: 881-890.

Block, B.A., Finnerty, J.R., Stewart, A.F.R., and Kidd, J. 1993. Evolution of endothermy in fish: mapping physiological traits on a molecular phylogeny. Science (Wash., D.C.), 260: 210-214.

Block, B.A., Dewar, H., Farwell, C., and Prince, E. 1998a. A new satellite technology for tracking the movements of Atlantic bluefin tuna. Proc. Natl. Acad. Sci. USA, 95: 9384-9389. 
Block, B.A., Dewar, H., Williams, T., Prince, E., Farwell, C., and Fudge, D. 1998b. Archival tagging of Atlantic bluefin tuna (Thunnus thynnus thynnus). Mar. Technol. Soc. J. 32: 37-46.

Block, B.A., Dewar, H., Blackwell, S.B., Williams, T.D., Prince, E.D., Farwell, C.J., Boustany, A., Teo, S.L.H., Seitz, A., Walli, A., and Fudge, D. 2001. Migratory movements, depth preferences, and thermal biology of Atlantic bluefin tuna. Science (Wash., D.C.), 293: 1310-1314.

Block, B.A., Boustany, A., Teo, S., Walli, A., Farwell, C.J., Williams, T., Prince, E.D., Stokesbury, M., Seitz, A., Weng, K. 2002. Distribution of western tagged Atlantic bluefin tuna determined from implantable archival and pop-up satellite archival tags. SCRS/02/094. ICCAT, Madrid, Spain.

Boustany, A.M., Marcinek, D., Keen, J., Dewar, H., and Block, B.A. 2001. Movements and temperature preferences of Atlantic bluefin tuna (Thunnus thynnus) off North Carolina: a comparison of acoustic, archival and pop-up satellite tags. In Methods and technologies in fish biology and fisheries. Vol. 1. Edited by J. Sibert and J. Neilson. Kluwer Academic Publishers, Dordrecht, Netherlands. pp. 89-108.

Burnett, C.D., Butler, M.J.A., Dickson, C.A., and Iles, T.D. 1977. Canadian tagging and recapture data of large pelagic fish for the period 1970-76. Coll. Vol. Sci. Pap. No. 6. ICCAT, Madrid, Spain. pp. 281-286.

Caddy, J.F., Dickson, C.A., and Butler, J.A. 1976. Age and growth of giant bluefin tuna (Thunnus thynnus thynnus) taken in Canadian waters in 1975. Fish. Res. Board Can. MS Rep. No. 1395.

Carey, F.G., and Lawson, K.D. 1973. Temperature regulation in free-swimming bluefin tuna. Comp. Biochem. Physiol. A Comp. Physiol. 44: 375-392.

Carey, F., and Teal, J.M. 1969. Regulation of body temperature by the bluefin tuna. Comp. Biochem. Physiol. 28: 205-213.

Gunn, J., and Block, B. 2001. Advances in acoustic, archival, and satellite tagging of tunas. In Tuna: physiology, ecology and evolution. Edited by B.A. Block and E.D. Stevens. Academic Press, San Francisco, Calif.

Hill, R. 1994. Theory of geolocation by light levels. In Elephant seals: population ecology, behaviour and physiology. Edited by
B.J. Le Boeuf and R.M. Laws. University of California Press, Berkeley, Calif. pp. 227-236.

Hill, R.D., and Braun, M.J. 2001. Geolocation by light-level. The next step: latitude. In Methods and technologies in fish biology and fisheries. Vol. 1. Edited by J. Sibert and J. Neilson. Kluwer Academic Publishers, Dordrecht, Netherlands. pp. 443-456.

Lutcavage, M., Brill, R., Skomal, G., Chase, B., and Howey, P. 1999. Results of pop-up satellite tagging on spawning size class fish in the Gulf of Maine. Do North Atlantic bluefin tuna spawn in the mid-Atlantic? Can. J. Fish. Aquat. Sci. 56: 173-177.

Magnuson, J.J., Safina, C., and Sissenwine, M.P. 2001. Whose fish are they anyway? Science (Wash., D.C.), 293: 1267-1268.

Mather, F.J., Mason, J.M., and Jones, A.C. 1995. Historical document: life history and fisheries of Atlantic bluefin tuna. NOAA Tech. Memo. NMFS-SEFSC-370.

McGowan, M.F., and Richards, W.J. 1989. Bluefin tuna, Thunnus thynnus, larvae in the Gulf Stream off the southeastern United States: satellite and shipboard observations of their environment. U.S. Natl. Mar. Fish. Serv. Fish. Bull. No. 87. pp. 613-631.

National Research Council. 1994. An assessment of Atlantic bluefin tuna. National Academy Press, Washington, D.C.

Richards, W.J. 1976. Spawning of bluefin tuna (Thunnus thynnus) in the Atlantic Ocean and adjacent seas. Coll. Vol. Sci. Pap. 2. ICCAT, Madrid, Spain. pp. 267-278.

Rivas, L.R. 1954. A preliminary report on the spawning of the western north Atlantic bluefin tuna (Thunnus thynnus) in the Straits of Florida. Bull. Mar. Sci. Gulf Caribb. 4: 302-322.

Sissenwine, M.P., Mace, P.M., Powers, J.E., and Scott, G.P. 1998. A commentary on western Atlantic bluefin tuna assessments. Trans. Am. Fish. Soc. 127: 838-855.

Taillade, M. 1992. Animal tracking by satellite. In Wildlife telemetry remote monitoring and tracking of animals. Edited by I.M. Priede and S.M. Swift. Ellis Horwood, New York. pp. 149-160.

Teo, S.L.H., Boustany, A., Blackwell, S., Walli, A., Weng, K.C., and Block, B.A. 2004. Validation of geolocation estimtes based on light and sea surface temperature from electronic tags. Mar. Ecol. Prog. Ser. 283: 81-91. 